ARTIKEL RISET

\title{
Pengembangan LKPD berbasis Problem Based Learning pada Materi Asam Karboksilat dan Ester untuk Kelas XII SMA/MA
}

\section{The Development of Problem Based Learning Student Worksheet on Carboxylic Acid and Esther Topics for $3^{\text {rd }}$ Grade of Senior High School}

\author{
T Fauziah ${ }^{1}$ and Suryelita ${ }^{*}$ \\ ${ }^{1}$ Pendidikan Kimia, Universitas Negeri Padang, Jl. Prof. Dr. Hamka, Air Tawar Barat, \\ Padang Utara, Sumatera Barat, Indonesia 25171 \\ *suryelita@yahoo.com
}

\section{ARTICLE INFO}

Received 17 October 2019

Revised 20 October 2019

Published 21 October 2019

\begin{abstract}
Carboxylic Acid and Esther in second semester of $3^{\text {rd }}$ grade High School was transferred to first semester due to the student's final exam, so the learning process was uneffective. Therefore it needs a 2013's curriculum compatible teaching materials as carboxyl acid and esther student worksheet which help students study independently. The aim of this research are to develop a PBL student worksheet and obtain its validity and practicality. The research using 4-D models: define, design, develop and disseminate, but the research was limited to develop stage. The research's instrument are validity and practicality questionnaire given to lecturers, teachers and 3rd grade students. The results was analyzed by Kappa Cohen Formula and gets a very high category. The validity from lecturers and teachers get 0,87 point, teacher's and student's practicality get each 0,93 and 0,83 point.
\end{abstract}

\section{KEYWORDS}

Carboxylic Acid, Esther, Student Worksheet, Problem Based Learning, 4-D Models, Validity, Practicalilty

\begin{abstract}
ABSTRAK
Materi asam karboksilat dan Ester kelas XII SMA/MA di semester genap dipindahkan ke semester ganjil karena peserta didik akan menghadapi ujian akhir. Sehingga pembelajaran menjadi tidak efektif.Untuk itu diperlukan bahan ajar berupa LKPD asam karboksilat dan ester sesuai kurikulum 2013 yang membantu peserta didik belajarmandiri. Tujuan penelitian adalah untuk mengembangkan LKPD berbasis PBLserta menentukan validitas dan kepraktisannya. Penelitian ini menggunakan model 4-D: define, design, develop, disseminate, tetapi penelitian dilakukan sampai tahap develop. Instrument penelitian adalah angket validitas dan kepraktisan yang diberikan kepada dosen, guru kimia dan peserta didik kelas XII.Hasil penelitian dianalisis dengan formula Kappa Cohen dan mendapatkan kategorisangat tinggi. Validitas oleh dosen dan guru memperoleh momen kappa 0.87, kepraktisan guru dan peserta didik mendapat momen kappa masing-masing 0,93 dan 0.83 poin.
\end{abstract}

\section{KATA KUNCI}

Asam karboksilat, ester, lembar kerja peserta didik, Problem Based Learning, model 4-D, validitas, kepraktisan 


\section{PENDAHULUAN}

Asam karboksilat dan ester adalah suatu senyawa organik yang mengandung gugus karboksil (-COO-). Perbedaannya senyawa asam karboksilat mengikat atom $\mathrm{H}$ pada gugus fungsi sedangkan senyawa ester mengikat alkil (R) pada gugus fungsi ${ }^{[1]}$. Materi asam karboksilat dan ester membahas struktur, tata nama, isomer, sifat fisika, reaksi kimia, sintesis, kegunaan, dan identifikasi gugus fungsi dengan spektrum inframerah. Materi ini berisi fakta, konsep, prinsip dan prosedur. Struktur asam karboksilat dan ester mempunyai keteraturan struktur yang saling berhubungan pada tata nama, sifat fisika, reaksi kimia dan sintesis. Keteraturanketeraturan ini dapat digunakan peserta didik untuk menemukan konsep sendiri.Materi asam karboksilat dan ester seharusnya dipelajari pada semester genap. Tapi semua materi semester genap kelas XII dipindahkan ke semester ganjil. Karena peserta didik kelas XII fokus membahas soal-soal secara intensif untuk persiapan ujian akhir nasional dan persiapan masuk perguruan tinggi. Akibatnya pembelajaran di semester genap termasuk asam karboksilat dan ester menjadi tidak efektif.

Berdasarkan hasil wawancara dengan beberapa guru SMA/MA di Padang diketahui bahwa telah menggunakan Kurikulum 2013 revisi. Guru menggunakan bahan ajar berupa buku teks dan LKS. Tapi LKS yang digunakan belum sesuai dengan kurikulum 2013 revisi, sehingga belum membantu peserta didik untuk menemukan konsep sendiri. Peserta didik belajar secara saintifik sesuai tuntutan kurikulum 2013.

Kurikulum 2013 menuntut peserta didik supaya secara aktif, mengolah dan mengonstruksi pengetahuan dalam proses pembelajaran dengan pendekatan saintifik ${ }^{[2]}$. Pendekatan saintifik mengharapkan peserta didik aktif untuk menemukan konsep dan menyelesaikan masalah secara sistematis serta meningkatkan kemampuan berfikir tingkat tinggi ${ }^{[3]}$. Salah satu solusi agar peserta didik dapat menemukan konsep sendiri adalah dengan adanya bahan ajar berupa Lembar Kerja Peserta Didik (LKPD) berbasis Problem Based Learning (PBL).

Model Problem Based Learning (PBL) adalah rangkaian aktivitas pembelajaran yang menekankan kepada proses penyelesaian masalah yang dihadapi secara ilmiah ${ }^{[4]}$. Sintak PBL terdiri atas lima fase yaitu 1. orientasi peserta didik pada masalah, 2. mengorganisasi peserta didik untuk belajar, 3. membimbing penyelidikan individual/kelompok, 4. mengembangkan dan menyajikan hasil karya serta, 5. menganalisis dan mengevaluasi proses pemecahan masalah ${ }^{[5]}$. PBL dapat digunakan dalam bahan ajar salah satunya dengan Lembar Kerja Peserta Didik (LKPD).

Lembar Kerja Peserta Didik (LKPD) merupakan lembaran-lembaran berisi tugas yang harus dikerjakan oleh peserta $\operatorname{didik}^{[6]}$. Tujuan dibuatnya bahan ajar dalam bentuk LKPD adalah agar dapat membantu peserta didik dalam menemukan konsep, penguatan/pemantapan konsep, penuntun pelajar, dan petunjuk praktikum ${ }^{[7]}$. LKPD berbasis Problem Based Leraning diharapkan dapat membantu peserta didik dalam menemukan konsep sendiri dan dapat memantapkan konsep yang telah ditemukan melalui permasalahan yang disajikan.

Penelitian sebelumnya terkait perkembangan lembar kerja peserta didik berbasis Problem Based learning telah dilakukan oleh Widya Farizka dengan materi Polimer Sintetis dan Karbohidrat. LKPD yang dihasilkan mempunyai kategori validitas dan praktikalitas oleh guru yang sangat tinggi dan kepraktisan oleh peserta didik tinggi ${ }^{[8]}$. Sedangkan Mitra Susantimeneliti dengan materi Haloalkana. Hasil penelitian dapat disimpulkan bahwa LKPD berbasis PBL mempunyai kevalidan dan kepraktisan menurut guru sangat tinggi dan kepraktisan peserta didik tinggi ${ }^{[9]}$. Tiara Handayani meneliti tentang Hidrolisis Garam dengan hasil kevalidan dan kepraktisan dari LKPD yaitu sangat tinggi ${ }^{[10]}$.

Berdasarkan uraian latar belakang diatas, maka penulis tertarik untuk melakukan penelitian yang berhubungan dengan Problem Based Learning. Dilakukan penelitian pengembangan LKPD berbasis PBL dengan judul "Pengembangan Lembar Kerja Peserta Didik (LKPD) berbasis Problem Based Learning (PBL) pada materi asam karboksilat dan ester untuk peserta didik kelas XII SMA/MA". Penelitian ini bertujuan untuk 1) menghasilkan LKPD berbasis PBL pada materi asam karboksilat dan ester serta 2) menentukan kategori validitas dan praktikalitas LKPD yang dikembangkan.

\section{METODE}

Jenis penelitian yang digunakan adalah penelitian dan pengembangan (Research and Development). Model pengembangan yang digunakan adalah 4-D (four D Models) yang terdiri dari 4 tahap yaitu 1) define (pendefenisian), 2) design (perancangan), 3) develop (pengembangan) dan 4) disseminate (penyebaran) $)^{[11]}$. Penelitian dibatasi sampai tahap develop. Subjek penelitian adalah dosen kimia FMIPA UNP, guru kimia dan peserta didik SMAN 4 Padang.

Pada tahap define dilakukan penetapan dan pendefinisian syarat-syarat pembelajaran. Dalam menentukan dan menetapkan syarat-syarat pembelajaran diawali dengan analisis tujuan dari batasan materi dengan menganalisis Kompetensi Dasar (KD) dan bahan materi pelajaran berdasarkan silabus kurikulum 2013 revisi. Langkah-langkah pada tahap define ini meliputi: a) Analisis Ujung Depan, b) Analisis Peserta Didik, c) Analisis Tugas, d) Analisis Konsep, e) Analisis Tujuan Pembelajaran.

Tahap design (perancangan) bertujuan untuk menyiapkan perangkat pembelajaran. Tahap ini terdiri dari 3 langkah, yaitu: pemilihan media, pemilihan format, dan melakukan rancangan awal LKPD. Rancangan awal LKPD dilakukan dengan melihat format-format yang sudah ada sebelumnya dan disesuaikan dengan sintak pembelajaran problem based learning. 
Tahap develop (pengembangan) bertujuan untuk menghasilkan LKPD berbasis problem based learning pada materi asam karboksilat dan ester yang valid dan praktis digunakan dalam proses pembelajaran. Tahap ini meliputi: a) Uji Validitas untuk mengetahui tingkat validitas dari LKPD yang dikembangkan; b) Revisi yang dilakukan dengan cara memperbaiki LKPD sesuai saran validator; c) Uji Praktikalitas untuk mengetahui tingkat kepraktisan LKPD yang dikembangkan.

Tahap disseminate (penyebaran) merupakan tahap penggunaan perangkat yang telah dikembangkan pada skala yang lebih luas. Penelitian dibatasi sampai tahap develop karena keterbatasan waktu dan biaya.

Instrumen pengumpulan data penelitian yang digunakan adalah angket validasi dan praktikalitas. Data yang diperoleh dianalisis menggunakan formula kappa Cohen di bawah ini.

$$
\text { moment kappa }(\kappa)=\frac{\rho_{0}-\rho_{\mathrm{e}}}{1-\rho_{\mathrm{e}}}
$$

Keterangan :

$\kappa=$ momen kappa

$\rho_{0}=$ Proporsi yang terealisasi

$\rho_{\mathrm{e}}=$ Proporsi yang tidak terealisasi

Tabel 1. Kategori Keputusan berdasarkan Moment Kappa $(\kappa)^{[12]}$

\begin{tabular}{c|c|c} 
Interval & Kategori & Keterangan \\
\hline $0,81-1,00$ & Sangat tinggi & $\mathrm{ST}$ \\
\hline $0,61-0,80$ & Tinggi & $\mathrm{T}$ \\
\hline $0,41-0,60$ & Sedang & $\mathrm{S}$ \\
\hline $0,21-0,40$ & Rendah & $\mathrm{R}$ \\
\hline $0,01-0,20$ & Sangat rendah & $\mathrm{SR}$ \\
\hline$\leqslant 0,00$ & Tidak valid & $\mathrm{TV}$
\end{tabular}

\section{HASIL DAN DISKUSI}

Hasil pengembangan LKPD Berbasis Problem Based Learning pada materi asam karboksilat dan ester menggunakan model 4-D diuraikan sebagai berikut:

\subsection{Tahap Define}

Tahap define terdiri dari beberapa tahap yaitu:

\subsubsection{Analisis Ujung Depan}

Berdasarkan hasil wawancara dengan guru SMAN 4 Padang diperoleh informasi bahwa pembelajaran materi Asam Karboksilat dan Ester menggunakan kurikulum 2013 revisi dan bahan ajar berupa buku teks dan LKS. TetapiLKS yang beredar tidak bewarna dan hanya berisi konsep singkat dari materi asam karboksilat dan ester. Pada umumnya pembelajaran Asam Karboksilat dan Ester dilakukan dengan meringkas materi, tidak dilakukan praktikum, dan mengerjakan soal latihan di kelas. Asam Karboksilat dan Ester merupakan materi kelas XII pada semester genap. Tapi materi semester genap kelas XII dipindahkan ke semester ganjil.
Karena peserta didik kelas XII fokus membahas soal-soal secara intensif untuk persiapan ujian akhir nasional dan persiapan masuk perguruan tinggi. Akibatnya pembelajaran materi semester genap termasuk asam karboksilat dan ester menjadi tidak efektif. Untuk itu dibuatlah bahan ajar berupa LKPD yang diharapkan mampu membantu peserta didik untuk dapat menemukan konsep sendiri .

\subsubsection{Analisis Peserta Didik}

Angket observasi peserta didik diberikan pada mahasiswa baru kimia kelas pendidikan kimia A tahun masuk 2018 karena peserta didik yang telah mempelajari materi asam karboksilat dan ester telah menamatkan studi pada tingkat sekolah menengah atas. Dari pengolahan angket peserta didik diperoleh $97 \%$ peserta didik menyukai materi asam karboksilat dan ester tetapi sebanyak 23\% peserta didik kesulitan pada materi asam karboksilat dan sebanyak $19 \%$ kesulitan pada materi ester. Peserta didik menggunakan LKPD sebanyak $19 \%$ dan melaksanakan praktikum sebanyak 13\% pada materi asam karboksilat dan ester. LKPD yang dirancang dapat membantu peserta didik untuk belajar menemukan konsep secara mandiri.

\subsubsection{Analisis Tugas}

Mengacu pada silabus kurikulum 2013 revisi, Kompetensi Dasar pada materi asam karboksilat dan ester adalah (3.9) Menganalisis struktur, tata nama, sifat, sintesis, dan kegunaan senyawa karbon. (4.9) Menyajikan rancangan percobaan sintesis senyawa karbon, identifikasi gugus fungsi dan/ atau penafsiran data spektrum inframerah (IR). Indikator dalam kurikulum 2013 revisi dikenal dengan Indikator Pencapaian Kompetensi (IPK). IPK untuk materi asam karboksilat dan ester yaitu : 1) Membedakan struktur senyawa asam karboksilaat dengan ester; 2) Menentukan nama IUPAC dan trivial dari struktur senyawa asam karboksilat dan ester ; 3) Menggambarkan struktur dari nama senyawa asam karboksilat dan ester; 4) Menggambarkan keisomeran asam karboksilat dan ester; 5) Menentukan sifat fisika senyawa asam karboksilat dan ester; 6) Meramalkan produk reaksi-reaksi kimia senyawa asam karboksilat dan ester dari persamaan reaksi; 7) Meramalkan reaksi-reaksi pembentukan/sintesis dari senyawa asam karboksilat dan ester; 8) Menjelaskan kegunaan senyawa asam karboksilat dan ester; 9) Mengidentifikasi gugus fungsi asam karboksilat dan ester dari spektrum inframerah (IR). Tugas-tugas dalam LKPD terdapat pada sintak membimbing pengalaman individual/kelompok, mengembangkan dan menyajikan hasil karya, menganalisis dan mengevaluasi proses pemecahan masalah.

\subsubsection{Analisis Konsep}

Konsep utama yang akan dibahas adalah materi Asam Karboksilat dan Ester. Konsep-konsep pada materi Asam Karboksilat dan ester yaitu Pengertian, penamaan asam karboksilat dan ester, isomer, sifat fisika, reaksi kimia, kegunaan, sintesis dan spektrum inframerah dari asam karboksilat dan ester. 


\subsubsection{Analisis Tujuan Pembelajaran}

Tujuan pembelajaran materi asam karboksilat dan ester adalah Melalui model pembelajaran Problem Based Learning dengan menggali informasi dari berbagai sumber belajar, penyelidikan sederhana dan mengolah informasi, diharapkan peserta didik terlibat aktif selama proses belajar mengajar berlangsung, Memiliki sikap ingin tahu, teliti, dalam melakukan pengamatan dan bertanggung jawab dalam menyampaikan pendapat, menjawab pertanyaan, memberi saran dan kritik, serta peserta didik mampu menganalisis struktur, tata nama, sifat, isomer, sintesis, dan kegunaan senyawa asam karboksilat dan ester serta dapat menyajikan rancangan percobaan sintesis senyawa asam karboksilat dan ester, identifikasi gugus fungsi dan penafsiran spektrum inframerah.

\subsection{Tahap Design}

Rancangan awal LKPD berbasis Problem Based Learning pada matreri asam karboksilat dan ester disusun berdasarkan format Depdiknas ${ }^{[13]}$ sebagai berikut :

\subsubsection{Judul}

Judul LKPD terdapat pada halaman cover. Halaman ini memuat gambar yang relevan dengan materi asam karboksilat dan ester seperti gambar struktur dan contoh asam karboksilat dan ester dalam kehidupan. Cover juga berisi identitas penulis seperti nama penulis, fakultas dan universitas, identitas pembimbing, dan kolom identitas untuk peserta didik.

\subsubsection{Informasi Pendukung}

Informasi pendukung terdiri dari kata pengantar, daftar isi, profil LKPD, peta konsep dan daftar pustaka.

\subsubsection{Petunjuk Penggunaan}

Petunjuk penggunaan akan memperjelaskan peran guru dan peserta didik dalam pembelajaran sesuai dengan sintak-sintak PBL. Untuk itu dibuatlah petunjuk penggunaan untuk guru dan peserta didik.

\subsubsection{Standar Kompetensi Lulusan (SKL)}

Bagian ini menentukan Kompetensi Inti (KI), dan Kompetensi Dasar (KD) dari materi pokok yang dipelajari. Berdasarkan hasil identifikasi KD, maka langkah selanjutnya diuraikan Indikator Pencapaian Kompetensi (IPK) dan tujuan pembelajaran yang akan dicapai peserta didik.

\subsubsection{Tugas dan Langkah Kerja}

Tugas dan langkah kerja terdapat pada bagian Pemahaman Materi yang berisi kegiatan belajar peserta didik pada pembelajaran asam karboksilat dan ester. Kegiatan ini disusun berdasarkan sintaksintak model Problem Based Learning yaitu :

1. Tahap Orientasi Peserta Didik terhadap Masalah. Guru menjelaskan tujuan pembelajaran, menjelaskan logistic yang diperlukan, dan memotivasi peserta didik terlibat pada aktivitas pemecahan masalah
2. Tahap Mengorganisasi Peserta Didik untuk Belajar. Guru membantu peserta didik mendefinisikan dan mengorganisasikan tugas belajar yang berhubungan dengan masalah tersebut.

3. Tahap Penyelidikan Individu/Kelompok. Guru mendorong peserta didik untuk mengumpulkan informasi yang sesuai, melaksanakan eksperimen untuk mendapatkan penjelasan dan pemecahan masalah.

4. Tahap Mengembangkan dan Menyajikan Hasil. Guru membantu peserta didik dalam merencanakan dan menyiapkan karya yang sesuai seperti laporan, dan membantu mereka untuk berbagai tugas dengan temannya.

5. Tahap Menganalisis dan Mengevaluasi Proses Pemecahan Masalah. Guru membantu peserta didik untuk melakukan refleksi atau evaluasi terhadap penyelidikan mereka dan proses yang mereka gunakan ${ }^{[5]}$.

\subsubsection{Penilaian}

Penilaian terdapat pada akhir bagian Pemahaman Materi dan dibuat per IPK. Terdapat 9 buah kolom penilaian dalam LKPD yang dibuat untuk masing-masing permasalahan.

\subsection{Tahap Develop}

Tahap develop terdiri dari uji validasi dan uji praktikalitas.

\subsubsection{Uji Validasi Bahan Ajar}

LKPD yang telah dikembangkan divalidasi oleh 2 orang dosen kimia FMIPA UNP dan 3 orang guru kimia SMAN 4 Padang, uji validasi dilakukan untuk menentukan kelayakan isi, komponen kebahasaan, kegrafikan dan penyajian dari LKPD yang dikembangkan. Hasil validasi dapat dilihat dalam Tabel 2.

Tabel 2. Hasil Analisis Validitas LKPD oleh Validator

\begin{tabular}{c|l|c|c} 
NO & Aspek yang Dinilai & $\begin{array}{c}\text { Momen } \\
\text { Kappa } \\
(\mathrm{K})\end{array}$ & Kategori \\
\hline 1 & Kelayakan Isi & 0.89 & ST \\
\hline 2 & Kebahasaan & 0.89 & ST \\
\hline 3 & penyajian & 0.87 & ST \\
\hline 4 & Kegrafikan & 0.78 & T \\
\hline \multicolumn{2}{r|}{ Rata-rata Validitas } & 0.87 & ST
\end{tabular}

Berdasarkan Tabel 2, Komponen kelayakan isi LKPD memiliki rata-rata momen kappa 0,89 dengan kategori kevalidan sangat tinggi. Aspek penilaian isi meliputi: kesesuaian dengan $\mathrm{KD}$, kesesuaian latihan dengan materi, kebenaran substansi materi pembelajaran, dan manfaat untuk penambah wawasan ${ }^{[13]}$. Hasil penilaian dari validator, LKPD berbasis Problem Based Learning pada materi asam karboksilat dan ester telah sesuai 
Edukimia $\cdot 2019 \cdot$ Vol. 1, No. 3

dengan kompetensi dasar, model pembelajaran yang digunakan sesuai dengan materi dan dapat membantu wawasan pengetahuan peserta didik.

Komponen kebahasaan memiliki rata-rata momen kappa 0,89 dengan kategori kevalidan sangat tinggi. Hal ini menunjukkan petunjuk dan informasi serta bahasa yang digunakan dalam LKPD sangat jelas dan mudah dimengerti. Namun ada sedikit saran perbaikan dari validator. Menurut Lasmiyati penggunaan bahasa yang komunikatif dan sedrehana membuat LKPD mudah dimengerti, sehingga dapat meningkatkan pemahaman konsep peseerta didik ${ }^{[14]}$.

Komponen penyajian memiliki rata-rata momen kappa 0,87 dengan kategori kevalidan sangat tinggi. LKPD yang dibuat sesuai dengan Indikator Pencapaian Kompetensi (IPK) dan tujuan pembelajaran. Sintak-sintak PBLtelah tergambarkan dalam LKPD. Pada komponen penyajian ini dinilai apakah sintaks model pembelajaran yang digunakan mengarah pada tercapainya tujuan pembelajaran ${ }^{[15]}$.

Komponen kegrafikan memiliki rata-rata momen kappa 0,78 dengan kategori kevalidan tinggi. Aspek penilaian kegrafikan meliputi: penggunaan font, layout, ilustrasi, dan desain tampilan ${ }^{[13]}$. Namun harus ada yang direvisi pada bagian font dan ilustrasi pada LKPD.

LKPD dirancang dengan Microsoft Word 2007 menggunakan font Maiandra GD ukuran 12. Struktur kimia digambar dengan ChemDraw professional 15.0 jenis huruf Times New Roman ukuran 12. Salah satu jenis huruf yang direkomendasikan untuk bahan ajar cetak adalah Times New Roman. Jenis huruf Times New Roman digunakan untuk dokumen resmi atau formal seperti buku, pedoman praktikum, makalah, dan karya ilmiah. Hasil rata-rata validasi dari LKPD yaitu 0,87 dengan kategori kevalidan sangat tinggi.

\subsubsection{Uji Praktikalitas}

Uji praktikalitas dilakukan untuk menentukan kepraktisan LKPD Asam Karboksilat dan Ester yang dikembangkan. Hasil kepraktisan dapat dilihat pada Tabel 3.

Tabel 3. Analisis Kepraktisan LKPD oleh Guru dan Peserta Didik

\begin{tabular}{c|c|c|c|c|c}
\multirow{2}{*}{ No } & $\begin{array}{c}\text { Aspek } \\
\text { yang } \\
\text { Dinilai }\end{array}$ & \multicolumn{2}{|c|}{ Guru } & \multicolumn{2}{c}{ Peserta Didik } \\
\cline { 3 - 6 } & $\mathbf{K}$ & Kategori & $\mathbf{~}$ & Kategori \\
\hline 1 & $\begin{array}{c}\text { Kemu- } \\
\text { dahan } \\
\text { Penggu- } \\
\text { naan }\end{array}$ & 0,93 & ST & 0,82 & ST \\
\hline 2 & $\begin{array}{c}\text { Efisiensi } \\
\text { Waktu } \\
\text { Pembe- } \\
\text { lajaran }\end{array}$ & 0,67 & $\mathrm{~T}$ & 0,88 & $\mathrm{ST}$ \\
\hline 3 & Manfaat & 0,95 & $\mathrm{ST}$ & 0,83 & $\mathrm{ST}$ \\
\hline
\end{tabular}

\begin{tabular}{c|c|c|c|c}
\multirow{2}{*}{ No $\begin{array}{c}\text { Aspek } \\
\text { yang } \\
\text { Dinilai }\end{array}$} & \multicolumn{2}{|c|}{ Guru } & \multicolumn{2}{c}{ Peserta Didik } \\
\cline { 2 - 5 } & K & Kategori & K & Kategori \\
\hline $\begin{array}{c}\text { Rata-rata } \\
\text { Kepraktisan }\end{array}$ & $\mathbf{9 , 9 3}$ & ST & 0,83 & ST
\end{tabular}

Berdasarkan Tabel 3 diperoleh hasil analisis data praktikalitas guru dan peserta didik dengan kategori sangat tinggi. Pada aspek kemudahan penggunaan LKPD memiliki kepraktisan sangat tinggi. Hal ini menunjukkan bahwa LKPD praktis dan mudah digunakan oleh peserta didik dan guru ${ }^{[16]}$.

Aspek efisiensi waktu pembelajaran memiliki kepraktisan oleh guru tinggi dan kepraktisan oleh peserta didik sangat tinggi. Karena materi asam karboksilat dan ester seharusnya diajarkan pada semester 2 namun karena akan menghadapi ujian nasional materi semester 2 dipadatkan ke semester 1 sehingga penggunaan LKPD di kelas kurang sesuai dengan waktu yang diberikan. Menurut Sukardi, salah satu pertimbangan praktis yang perlu diperhatikan adalah waktu penggunaan LKPD sendiri sebaiknya singkat, cepat dan tepat ${ }^{[17]}$.

Pada aspek manfaat memiliki kepraktisan oleh guru dan peserta didik sangat tinggi. Hal ini menunjukkan bahwa LKPD Berbasis PBL pada materi asam karboksilat dan ester praktis dan mudah digunakan serta membantu peran guru sebagai fasilitator dalam pembelajaran. Menurut Salirawati, LKPD memudahkan guru dan peserta didik dalam kegiatan belajar-mengajar dan menemukan konsepkonsep sendiri ${ }^{188]}$.

\section{SIMPULAN}

Berdasarkan penelitian yang dilakukan, dapat disimpulkan bahwa LKPD Berbasis PBL pada materi asam karboksilat dan ester telah dihasilkan dan memiliki kevalidan sangat tinggi. Kepraktisan LKPD oleh guru dan peserta didik memiliki kategori sangat tinggi.

\section{REFERENSI}

1. Fessenden, R I, dan Fessenden, JS. Dasar-dasar Kimia Organik. Jakarta: Bina Aksara; 1997.

2. Permendikbud No 59 Tahun 2014 Tentang Kurikulum 2013 Sekolah Menengah atas/ Madrasah Aliyah. Jakarta.

3. M.Hosnan. Pendekatan Saintifik dan Konstektual dalam Pembelajaran Abad 21. Bogor: Ghalia Indonesia; 2014.

4. Sanjaya, Wina. Strategi Pembelajaran Berorientasi Standar Proses Pendidikan. Jakarta: Kencana Prenada Media Group; 2009.

5. Rusman. Model-Model Pengembangan Profesionalisme Guru. Jakarta: Rajawali; 2012.

6. Majid, A. Perencanaan Pembelajaran Mengembangkan Standar Kompetensi Guru. Bandung: PT.Remaja Rosdakarya; 2012.

7. Amri, S. Pengembangan dan Model Pembelajaran dalam Kurikulum 2013. Jakarta : 
PT.Prestasi Pustakaraya; 2013.

8. Farizka, W dan Suryelita. Pengembangan Lembar Kerja Peserta Didik (LKPD) Polimer Sintetis dan Karbohidrat Berbasis Problem Based Learning Untuk Kelas XII SMA/MA. Iournal of Residu, Vol. 3 Issue 13;2019.

9. Susanti, M dan Suryelita. Pengembangan Lembar Kerja Peserta Didik (LKPD) Berbasis Masalah (Problem Based Learning) pada Materi Haloalkana untuk Kelas XII SMA/MA.Journal of Residu, Vol. 3 Issue 13 hlm. 11-17; 2019.

10. Handayani, $T$ dan Suryelita. Pengembangan LKPD berbasis Problem Based Learning pada Materi Hidrolisis Garam untuk Kelas XI SMA/ MA.Journal of Technique Research/ITR. Vol.1 Issue 2 hlm. 197-204; 2019.

11. Trianto. Mendesain Model Pembelajaran Inovatif-Progresif. Jakarta:Kencana; 2009.

12. Boslaugh, S dan Paul A. W. Statistics in a Nutshell, a Desktop Quick Reference. Beijing, Cambridge, Famham, Köln, Sebastopol, Taipei,Tokyo: O'reilly; 2008.

13. Departemen Pendidikan Nasional. Pengembangan Bahan Ajar. Jakarta: Departemen Pendidikan Nasional, Direktorat Jenderal Manajemen Pendidikan Dasar dan Menengah, Direktorat Pembinaan Sekolah Menengah Atas; 2008.

14. Lasmiyati. "Pengembangan Modul Pembelajaran untuk Meningkatkan Pemahaman Konsep dan Minat SMP”. Jurnal Pendidikan Matematika, Vol 9, No 2, 161-174; 2014.

15. Rochmad. "Model Pengembangan Perangkat Pembelajaran Matematika, Desain Model Pengembangan".Jurnal Kreano, ISSN 20862334, Vol 3, No.1; 2012.

16. Nieveen, N. Prototype to reach product quality. Dlm. Van de Akker, I., branch, R.M., Gustafson, K., Nieveen. N., \&Plomp, T. Design apporoaches and Tools in Educational and Training. Dordrecht: Kluwer Academic Publisher; 1999.

17. Sukardi. Evaluasi Pendidikan dan Operasionalnya. Yogyakarta :Bumi Aksara; 2008.

18. Salirawati, D. Penyusunan dan Kegunaan LKS dalam Proses Pembelajaran. Jurnal; 2008. 